chemists and druggists. It contains details of the examinations of the Pharmaceutical Society, both the minor examination and the major, a list of prizes, sundry tables, and a list of Latin terms used in prescribing, with translations of the same. Altogether, the class for which it is written should find it very useful.

Low's Handbook to the Charities of London, 1906. Seventyfirst year of publication. London: Eliot Boothroyd. Pp. xxxii.-286. Price 1s.-This excellent little book is arranged alphabetically, so that it is easy to find any particular charity. Like all guides to charities, it contains details of a number of societies the work of which can in no sense be called charitable. For those who wish to contribute to real charities, however, the book is an admirable help, although it does not pretend to enter into such a detailed account of charity and charities as does the work noticed below.

The Annual Charities Register and Digest, 1906. London: Longmans, Green, and Co., and the Charity Organisation Society. Pp. cccii.-688. Price 5s.-This well known compilation is indispensable to every almsgiver. The introduction by Mr. C. S. Loch is a mine of information in itself and the index is a model of what an index should be. A new feature in the present volume is a series of articles upon special branches of charitable work written by experts in the particular subject of which they treat. "A Review of the Year" is another addition. Our remarks about charities which are no charities, but rather polemical politico-religious societies, apply to this book as to nearly all other charity guides. We hold no brief either for or against such societies, we merely contend that they should not call themselves charities.

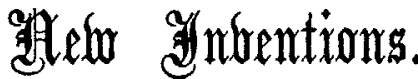

\section{A NEW DIRECTOR FOR BLIND INTERNAL} FISTULA.

IT may happen that in cases of blind internal fistula difficultiy may be experienced in finding the opening and passing an ordinary probe into the sinus. To accomplish this manceuvre it usually means that the probe has to be bent to a greater or less degree. To overcome this difficulty I bave devised an instrument of which the accompanying

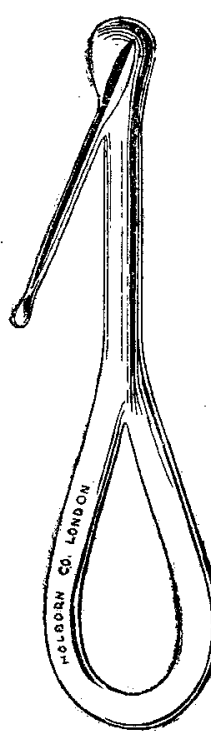

illustration is a representation. It consists of a straight stem terminating above in a bulbous extremity and expanding below into a broad handle. The length of the stem is three and a half inches. From the stem runs a straight probe-pointed director one and three-quarter inches in length and set at an angle of 23 degrees. There is a groove on both sides of the director which is carried almost up to the point on the one hand and obliquely on to the stem on the other. The special points about this instrument are: (1) its top is bulbous, so that when it is inserted it can do no harm to the mucous membrane; (2) the groove being on both sides of the probe-pointed director enables the surgeon to slit up the tissues overlying the fistula, no matter where the latter may be situated; and (3) the handle being broad the instrument can easily be rotated into any position desired. The makers of the instrument are the Holborn Surgical Instrument Company, who have admirably carried out my suggestions.

Orcil H. LeaF, M.B., B.C.Oantab., F.R.C.S.Eng., Surgeon to the Cancer Hospital and Gordon Hospital

Wimpole-street, $\mathbf{W}$.

\section{ILoking JBack.}

\author{
FROM \\ THE LANCET, SATURDAY, May 24th, 1828.
}

\author{
FOREIGN DEPARTMENT.
}

ANOMALY OF VISION. BY M. J. GODMAN.*

THE inversion of images formed on the retina, by the passage of rays of light through the anterior part of the eye, resulting from the laws of opties, is constant, and does not produce any uncertainty in the judgment relative to the position of the objects, provided the other senses be in their natural condition. The following case presents an extremely interesting exception :-A child, seven years of age, the son of a distinguished artist, commenced taking lessons in drawing from his father; but it may be imagined how great the parent's surprise was at finding all the objects which the child represented, drawn upside down. It was first supposed that the child might be practising this inversion of objects in joke, but he affirmed that he drew the objects as they appeared to him; and as the drawings were, in other respects, very accurate, there was no reason for doubting the child's word. Every time that the object was turned before he took a sketch of it, he represented it in the natural position, showing that the sensation received by the eye corresponded perfectly with the inversion formed on the retina. This state of vision continued more than a year after which time the child began to see objects in their natural position.

Many analogous cases have been observed; a very distinguished lawyer, for instance, saw, for some time, objects inverted; the houses appeared to him to rest on the roofsmen, to walk on their heads, \&c. This aberration of vision depended on a disturbed state of the digestive organs, and disappeared with the cause which gave it origin. $\mathrm{Dr}$. Wollaston, after considerable exercise of body and mind, suddenly found that he could see but half of the figures of persons whom he met, as well as other objects which came before him. Dr. Crawford relates the history of a woman who was attacked with a slight hemiplegia of the left side, who, from that period, could see but half an object, not even after that the power of motion had been restored to the paralysed side. Another person had, for several years, a derangement in the vision of the right eye, to which every single object was represented multiplied seven or eight times.

$$
\text { * Journal Universel des Sciences Med. Feb. } 1828 .
$$

Asylum Workers' Association.-The annual general meeting of this society (founded in 1895 to improve the status of asylum nurses and attendants, to provide for them "homes of rest and nursing," and to enlist public sympathy in their work) will be held at the Medical Society's house, 11, Chandos-street, Cavendish-square, London, W., on Friday, June 1st, at 4 P.M. Sir John Batty Tuke, M.P. (president of the association), will take the chair. There will be a presentation of two gold and two silver medals awarded by the association for long and meritorious nursing service. All interested in asylum work and workers are cordially invited to attend.

The Panhellento Medical Congress at ATHENs.- The Fifth Panhellenic Medical Congress has just taken place at the Greek capital. It lasted a week and closed at the time when the Olympic games were brought to an end. The King of Greece and the Royal Family were present at this Congress and the Minister of Public Instruction opened it, in his capacity of president, with an eloquent discourse on the progress of medical science generally. The work of the Congress has been divided into two sections-a pathological one which held its meetings in the halls of the University and a surgical one which gathered in the academy rooms. It is reported from Athens that there was a large influx of foreign medical men desirous of attending the Congress. At its close the President announced the formation of a joint-stock society for the purpose of exploitation of all the mineral waters of Greece. He also communicated the news that this society offers 2000 drachmas (one drachma $=$ one franc) for the best work on the curative properties of the mineral waters of Greece. 